\author{
Aneta Pawłowska-Legwand \\ https://orcid.org/0000-0001-7819-6312 \\ Jagiellonian University in Kraków \\ Faculty of Geography and Geology \\ Institute of Geography and Spatial Management \\ aa.pawlowska@uj.edu.pl
}

\title{
USE OF INFORMATION AND COMMUNICATION TECHNOLOGY TO ACCESS TOURIST INFORMATION AND SERVICES: THE RESULTS OF RESEARCH CONDUCTED AMONG POLISH TOURISTS IN MAŁOPOLSKA VOIVODESHIP ${ }^{1}$
}

\begin{abstract}
Information and communication technology (ICT) is widely used to access tourist information and services, and as a result using digital tools and sources influences tourist behaviour. The main goal of this paper, based on research, is to describe the behaviours and opinions of tourists who used ICT before travelling. The results include the evaluation of the usefulness of digital tools from a tourist's point of view, and indicates that tourists are interested in using ICT. Respondents aged over 35, who are living in cities and have had at least secondary education or a university degree, are more active users of digital tools. Websites, mobile applications and other ICT uses have been treated by respondents primarily as a source of tourist information in its widest sense, and a tool which facilitates the process of planning travel routes and purchasing travel-related services. Social media, which facilitate sharing travel-related content, also have a major significance.
\end{abstract}

Keywords: information and communication technology, tourist information and services, surveys, focus group research.

\section{INTRODUCTION}

In recent years, the role of information and communication technology (ICT) has increased and allowed access to information and online services, and this is related to the development of the information society (Giddens, 2008). This growth concerns the tourist information and services which can be accessed using various digital sources and tools. One of the results of technological development is the development of e-tourism (Buhalis, 2003) and smart tourism, both of which are related to 'big data' and the 'internet of things' (Gretzel, Sigala, Xiang, Koo, 2015).

A stage in the search for information and the use of such information is an essential part of tourist behaviour concerning both the model of tourist behaviour in geographical space (Hall, 2006; Kowalczyk, 2000; Mika, 2014; Richards, 2002) and consumer behaviour on the tourism market (Kotler, Bowen, Makens, 2006). From the perspective of the consumer, access to ICT may increase the usability of space and time related to tourist information and services of various types as well as decreasing the costs of these activities (Kachniewska, 2011). Through digital sources and devices, consumers can gain knowledge, reduce purchase risk and shape their perception of travel
(Kotler, Bowen, Makens 2006). The key significance for the use of digital devices is their perception as useful for various travel activities (Amaro, Duarte, 2015; Kim, Park, Morrison, 2008; di Pietro, di Virgiglio, Pantano, 2012). To descibe relations between a tourist and the geographical space, Mika (2014) emphasized that the cognition and valuation of geographical space, related to the search and the use of information about tourist attractions and facilities, precedes the use of geographical space to realize needs. Travel is described as an activity requiring time, funds and the emotional involvement of individuals. That is why access to accurate, verified and reliable information is of major significance (Marciszewska, 2010). However, Horner \& Swarbrooke (2016) turned their attention to emotional motivators. On the one hand, such motivators may decrease an individual's involvement in searching for information before the decision to make a travel-related purchase, and on the other hand, they may result in a search for more detailed information (Horner, Swarbrooke, 2016).

Apart from perceptions of usability, the results of research focused on the digital tools used by tourists, while 
the creation of tourist experience is also emphasized. Contemporary consumers are characterised as being increasingly independent, self-reliant and exacting when they search for information before deciding on a purchase related to travel (Niininen, Buhalis, March, 2007). Consumers search for information and products or services that suit their needs as optimally as possible (Niemczyk, 2017a) to have authentic and unique experiences as well as providing good value for their time and money (Gaworecki, 2007). The main goal for the consumers is to find a satisfying compromise between quality, price (Buhalis, O'Connor, 2005) and tourist experience (Zehrer, Pechlaner, Hölzl, 2005). In this context, ICT is significant for purchasing, consuming and recalling the tourist experience (Horner, Swarbrooke, 2016). Using digital sources and tools may empower purchase decisions (Buhalis, O'Connor, 2005; Buhalis, Law, 2008; Niininen, Buhalis, March, 2007;) and co-create pre-tourism experience, on-site tourism experience, and post-tourism experience (Neuhofer, Buhalis, Ladkin, 2012, 2014).

Neuhofer, Buhalis \& Ladkin (2014) described three levels of tourism experience depending on the scope of the use of digital tools. According to this model, ICT cocreates the tourism experience. The levels include the use of various aspects such as reservations systems, virtual travel agencies, social media, mobile technology and devices, as well as location-based services and augmented reality (Neuhofer, Buhalis, Ladkin, 2014). Panasiuk (2015) described the behaviours of e-tourists and noticed a diversity in the ways these consumers use sources and tools on the internet to make purchase decisions related to services and destinations. Consumers can use digital sources and tools to support their decisions, use both digital and analogue, or use digital only to make reservations and purchase decisions. This choice depends on perceived benefits (Panasiuk, 2015).

Social media have gained particular significance in tourism during recent years. As a result of two features, interactivity and user-generated content, users tend to view these sources as credible and useful, as well as quick and easy availability (Law, Buhalis, Cobanoglu, 2014). This kind of content is opinion-forming and as a result can create opinions and trends influencing the needs and behaviours of users, including those related to tourism (Buhalis, Leung, Law, 2011; Meyer, 2015; Xiang, Gretzel, 2010; Zeng, Gerritsen, 2014). What is more, sharing tourism experiences on the internet is treated as an activity providing content useful for other users and tourists (Munar, Jacobsen, 2014).

Xiang, Magnini \& Fesenmaier (2015) noticed a characteristic bifurcation in consumer behaviour related to the use of online sources and tools for planning journeys. This stage can be based on the use of well-known set of sources and tools as a result of habit or on the use of increasingly varied and numerous sources and tools such as social media, mobile applications and online travel agen- cies for planning as optimal a tourism experience as possible. It is important that the use of digital sources and tools can be combined with analogue. Additionally, access to the internet is a cause of a major changes in planning and can be postponed by tourists until after they arrive at a destination (Xiang, Magnini, Fesenmaier, 2015).

Currently, the use of ICT is indicated in tourism reports as one of the trends shaping this economic sector in the medium and long term, as Rudnicki (2017) described in detail in his paper. The digital channels of tourist information and service distribution, including e-agents, will develop and consumer behaviours will be exhibited on the internet more widely. This kind of consumer activity allows analysis and then application of 'big data' about behaviour in business processes. Social media are related to the increased significance of the content provided by online creators and influencers such as bloggers and vloggers, as well as content reviews by users. As a result, this kind of content will shape not only consumer behaviour but also the marketing of a place or a destination. It is anticipated that mobile technology, virtual reality and semantic searching will find wider applications (Rudnicki, 2017).

\section{REVIEW OF CURRENT RESEARCH RESULTS CONCERNING TOURISTS IN POLAND}

The growing availability, variety and popularity of digital sources of tourist information and tools allowing access to services created with ICT has caused increased interest in tourists focused on using digital solutions. As Jaremen, Michalska-Dudek \& Rapacz (2016) noticed, on the tourism market the phenomenon of virtualisation of consumer behaviour exists because currently tourists use the internet to realise their information needs for successive stages of travel. From a broader point of view, the development of ICT has allowed the digitalization of information (Kachniewska, 2017) and the use of digital sources and devices creates tourism experience (Berbeka, 2017).

Interest in using the internet, increasingly treated as the main information source about tourist attractions $(60 \%)$, is related to not purchasing printed thematic publications $(54.8 \%)$, but customers still rarely abandon travel agencies (9.9\%) (Jaremen, Michalska-Dudek, Rapacz, 2016). This part of consumer behaviour is related to the characteristics of the e-consumer presented by $\mathrm{Pa}-$ nasiuk (2015). At the decision stage for a preferred tourism destination, not only access to sources of information is important, but also the way this information is visualized (Kachniewska, 2017). The content of various social media, including photographs, is indicated as one of the most important factors influencing consumer behaviours related to tourism (Poczta, Mariianchuk, 2013). 
The results of a survey conducted by Jaremen, Michalska-Dudek \& Rapacz (2016) in the Lower Silesia Voivodeship $(\mathrm{n}=343)$ indicate a high interest of respondents in searching for information on the internet (see Smul, 2013), both before travel (90\%) and while travelling $(83 \%)$. Similar results have been obtained in a survey in Kraków (n=1175) as presented by Berbeka (2017). Before travelling, respondents used various information sources such as thematic websites (59.55\%), official websites of local or regional government or tourism organizations $(42.21 \%)$, and social media including Facebook and blogs (ca. 40\%). The internet has gained significance as a tool to purchase tourist services $(81 \%)$, mostly accommodation (71.46\%) (mainly Booking.com), and tickets for different means of transport, mostly train or bus $(63.21 \%)$, and plane $(54.02 \%)$. The respondents rarely bought tickets for public transport in cities $(24.95 \%)$ (Berbeka, 2017).

Among Polish tourists there is a growing interest in using social media for the purpose of their own travel, both in information searching, such as querying usergenerated content, and in sharing information related to their journeys (Berbeka, 2017; Jaremen, MichalskaDudek, Rapacz, 2016; Niemczyk, 2017b; Seweryn, 2015). This kind of information, in turn, may be analysed from different perspectives. Zajadacz (2017) provided an example of research on dissatisfaction with tourist attractions on the basis of content from TripAdvisor.

Interest in using social media concerns not only various kinds of social network but also (and mainly) online creators and influencers. Jakubowska (2018), on the basis of a content analysis of Polish blogs related to travel $(n=41)$, noticed that bloggers popularized selected types of tourism. The analysis listed leisure tourism $(100 \%)$, sightseeing (98\%) and sports-based tourism $(55 \%)$, in cities $(93 \%)$, seaside resorts (61\%), and mountainous areas $(54 \%)$. These types mainly concerned domestic tourism (66\%) (Jakubowska, 2018). In turn, Lisowska \& Wieszaczewska (2017) emphasized the role of this content and narration as a medium influencing tourists' needs and perceptions (see Morozova 2016). Even though Lisowska \& Wieszaczewska (2017) analysed entries devoted to pilgrimages to Santiago de Compostela $(n=5)$ retrieved from travel blogs, it can be said that this influence may also concern other types of tourism. Morozova (2016), on the basis of content analysis of travel blogs $(\mathrm{n}=23)$ as well, noticed the influence of bloggers' advice for planning journeys. The advice included broadly-defined tips, rankings and test results. Readers of the blogs who are potential tourists may treat this information as recommendations for places or equipment, useful in planning (Morozova, 2016). Blogs can be a tool of promotion for certain patterns (Morozova, 2016) and alternative ways of travelling (Jednoralska, 2016). From this perspective, tourists' opinions and behaviours related to user-generated content in social media may be a worthwhile area of study.
Access to tourist information and services has become increasingly popular due to the use of mobile applications. Kubiak (2015) conducted a survey $(n=103)$ using the example of applications dedicated to the cities of Torun and Poznan and described their usefulness. The respondents used smartphones to obtain tourist information in two ways: directly from mobile applications (25\%) and from the internet (ca. 30\%). The most important features were usefulness (34\%) and available content $(21 \%)$. On the basis of these two features tourists evaluated mobile applications as useful and satisfying their need for information. A compilation of user ratings from online stores presented by Zawadzki (2018) allows more to be learned about the interest of tourists in using mobile applications dedicated to selected Polish cities (ratings from 3.0 to 4.6 ) and regions (ratings from 3.9 to 4.8$)$.

The method and scope of the use of digital tools by Polish tourists is influenced by demographic and social characteristics. The 'younger' age groups are more interested in the use of these tools, and this phenomenon is related to traits of $\mathrm{X}, \mathrm{Y}$ and $\mathrm{Z}$ generations. These generations are more active in travelling and using ICT, including the planning stage (Zajadacz, 2014). Respondents below 35 more often use digital tools to plan and arrange travel (Jaremen, Michalska-Dudek, Rapacz, 2016; see Berbeka, 2017). Apart from age, other demographic and social characteristics also influence the use of digital sources of tourist information such as place of residence, education, and professional status. While decisions connected to electronic payments for tourist services are affected by their financial situation (Berbeka, 2017). Concerning age, similar relationships were observable in the results of surveys conducted in Kraków ( $\mathrm{n}=3651$ ) presented by Seweryn (2015) which focused on searching for tourist information in the social media. The more active respondents were younger than 40 and living in major cities (Seweryn, 2015). The results of a survey conducted by Rasińska \& Siwiński (2015) in Poznań showed that according to respondents in higher education (97\%), mobile applications combining multiple functions can replace printed travel guides, cameras, and GPS tracking devices.

The use of ICT by Polish tourists is often the main goal of a survey. However, the 'big data' generated during this use can be analysed, for example demographic, on purchase decisions, opinions and impressions (Kachniewska, 2014). Majewska, Napierała \& Adamiak (2016) noticed, using the example of an analysis of photographs taken in Kraków Metropolitan Area and then shared on Wikimedia Commons, that this type of content may be considered useful to evaluate the attractiveness of selected places and areas for tourist activities and tourism development in a wide sense. Kachniewska (2014) presented the results of an expert panel and listed the advantages of 'big data' analysis, such as forecasting and 
analysing consumer trends that allow new products to be created on the basis of the results. From a broader perspective, the use of 'big data' concerns the design of individual and comprehensive tourist experience. As a result, these activities may provide a competitive advantage for businesses and tourism destinations (Kachniewska, 2014).

\section{AIM AND METHODS OF RESEARCH}

The main goal of this paper is to describe the behaviours and opinions of tourists related to using ICT before travel on the basis of research results (cf. Pawłowska, 2015 2016a, b). To research the level and the range of activity of tourists focused on the use of digital tools, two methods were applied, a survey and focus group research, with the second supplementing the results of the first. The paper focuses on the presentation of the use of a range of digital tools and an evaluation of their usefulness.

The survey was conducted from 2014 to 2016 in tourism destinations in Małopolska Voivodeship $(n=1053)$ and was based on a random selection. These destinations were Kraków ( $\mathrm{n}=400)$, Krynica-Zdrój $(\mathrm{n}=100)$, Nowy Targ $(n=300)$, Szczawnica $(n=100)$, Wieliczka $(n=53)$ and Zakopane $(n=100)$. The survey was divided into three stages: September 2014 through December 2014, March 2015 through September 2015, February 2016 through June 2016. A standardised questionnaire of 25 questions was used and the interviewer completed it during a conversation with a respondent. The questionnaire contained 24 closed questions and one open. The respondents in this survey were domestic tourists with or without accommodation.

In the statistical analysis, answers from $\mathrm{n}=973$ respondents were taken into account: $51 \%$ were women and $49 \%$ were men. As to age, $30 \%$ were aged from 19 to $25,31 \%$ from 26 to 35 , while $36 \%$ were over 35 . The percentage from the youngest age group (15-18) was $4 \%$. The majority of respondents lived in cities $(87 \%)$, with one third in cities of over 500,000 inhabitants (34\%). Half of the respondents had a university degree and higher education, 39\% with high school or secondary, $7 \%$ vocational, and 3\% elementary. $91 \%$ had been students of high or secondary schools.

The focus group research was conducted in 2016 on the basis of sampling after the survey was finished. The results showed that tourists from 15 to 35 used ICT more often and more actively in the context of travelling, so focus group research was conducted with respondents from this age group recognising the investigated issues from their point of view in detail.

Open questions were asked according to a scenario. The interviews were registered on a digital device and then a transcript was prepared. In the paper, the results of the interviews are presented. Respondents from 15 to 35 took part $(n=45), 60 \%$ were women and $40 \%$ men. The participants were divided into five focus groups. Interviews with 'younger' respondents (from 15 to 18) who had completed elementary education, lasted from 45 to 60 minutes, while interviews with 'older' respondents (from 19 to 35) after secondary education plus higher education, lasted from 60 to 90 minutes. The 'younger' respondents were divided into two groups of 15 each, and the 'older' into three groups of 5 each. The respondents were urban residents with $66 \%$ of them living in cities with population of over 500,000.

\section{RESEARCH RESULTS}

\subsection{USING ICT BEFORE TRAVELLING}

Nearly $70 \%$ of respondents always used the internet $(31 \%)$ or used it often $(35 \%)$ when they were planning and arranging a journey. While $12 \%$ used the internet rarely, and $4 \%$ never. This question was the introductory one and issues related to using digital tools were investigated in detail with further questions.

On the basis of respondents' answers and their demographic and social characteristics it was possible to observe some distinctive features, similar to many other questions. Taking into account age groups, the more active users were among respondents under the age of 35 (Kruskal-Wallis test: $H=53.13, p=0.000$ ) (Table 1). Another showed that the more active were those with higher education and a university degree (Kruskal-Wallis test: $H=100.96, p=0.000$ ). The participants who answered that they 'always' or 'often' used the internet amounted to $76 \%$, similar to those with elementary education (72\%). Fewer of those with secondary education provided the same answers (59\%), and the proportion with vocational education was the lowest (26\%). About $30 \%$ of respondents with vocational education did not use the internet. Those living in cities with a population of over 500,000 provided more 'always' and 'often' answers than those from smaller cities and towns or from rural regions (Kruskal-Wallis test: $H=156.27, p=0.000$ ). Over half of respondents always used the internet $(56 \%)$ and over a quarter used the internet often $(28 \%)$.

Respondents when asked about the goals of using the internet for travel purposes (Fig. 1) answered that they most frequently searched for tourist information (85\%). They primarily used the website of the visited place or destination (56\%), for example an official local government website. The second digital source mentioned was a thematic nationwide web portal with a tab dedicated to travelling $(42 \%)$. Less frequent answers indicated the- 
Table 1. Frequency of internet use before travelling according to age group (\%)

\begin{tabular}{|c|c|c|c|c|c|c|c|}
\hline \multirow{2}{*}{$\begin{array}{c}\text { Frequency of using } \\
\text { the internet }\end{array}$} & \multicolumn{6}{|c|}{ Response rate according to age group (\%) } & \multirow{2}{*}{ Kruskal-Wallis test ${ }^{2}$} \\
\hline & $15-18$ & $19-25$ & $26-35$ & $36-45$ & $46-55$ & $>55$ & \\
\hline Always & 41 & 35 & 31 & 27 & 28 & 18 & \multirow{6}{*}{$H=53.13, p=0.000$} \\
\hline Often & 28 & 44 & 40 & 28 & 16 & 18 & \\
\hline Sometimes & 21 & 16 & 23 & 33 & 24 & 8 & \\
\hline Rarely & 7 & 2 & 5 & 11 & 22 & 10 & \\
\hline Never & 3 & 3 & 1 & 1 & 10 & 46 & \\
\hline Total & 100 & 100 & 100 & 100 & 100 & 100 & \\
\hline
\end{tabular}

a Statistically significant differences $p<0.05$.

Source: author.

matic travel websites (36\%), for example created by local government too. The respondents were interested in content reviews, for example, about accommodation, indicated by $36 \%$ (Fig. 1). They rarely used social media other than rating systems and online forums (42\%), for example blogs and videoblogs (35\%), Facebook (30\%) or online encyclopaedias (30\%). These kinds of digital sources of tourist information were used by respondents younger than 35 . The rating systems and online forums were chosen by ca. $50 \%$ of respondents, Facebook by ca. $35 \%$, and blogs and videoblog by ca. $30 \%$. These answers were indicated by one in five respondents or one in six respondents older than 35 .

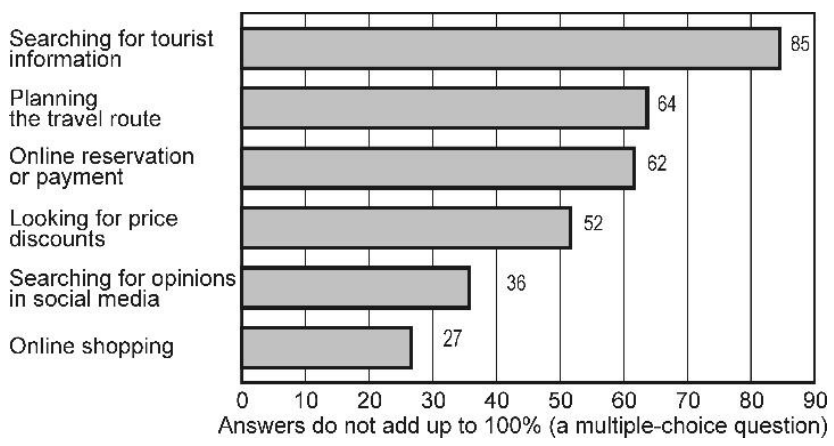

Figure 1. Reasons for using the internet before travelling (\%) Source: author

Sharing information about one's own journey on social media was declared by $44 \%$ of respondents and they were the most active while travelling. Before a journey they mainly added check-in information $(3 \%)$ or shorter $(3 \%)$ and longer postings (2\%). Respondents under 35 were more active on social media and mainly from the group between 15 and 18. This activity was related to the frequency of using the internet before travelling ( $\chi^{2}$ Pearson test $=98.33, p=0.000$ ).

Because nearly $30 \%$ of respondents searched for opinions on social media (36\%) during focus group interviews, they were asked about their interest in the activity of social media influencers, for example bloggers and vloggers, in the context of their own journey. This interest was observable among both 'younger' and 'older' respondents however the reasons were different (Fig. 2). The

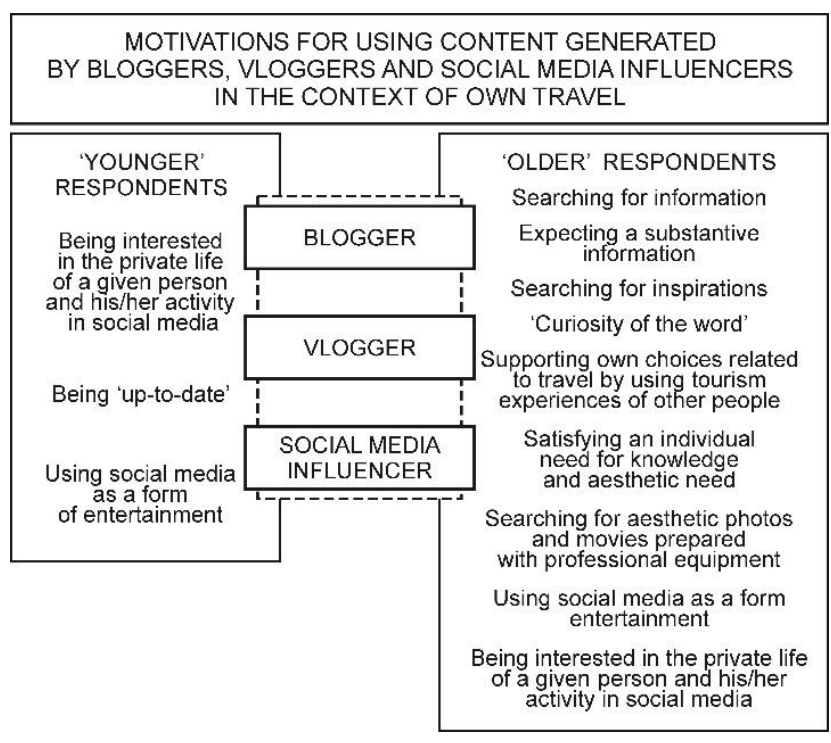

Figure 2. Motivations for using content provided by social media influencers in the context of travel Source: author

opinions of 'older' respondents were focused on the influence of social media content on their own decisions related to travel, because of some features such as substantive information, narration and storytelling, aesthetics, and the professional preparation of posts, videos and photographs. This was done for example using a GoPro sport video camera dedicated for use when performing extreme sports, or a drone. The 'older' respondents were aware that the shared content may be a product of commercial cooperation and marketing communication, and because of this, the majority treated such content as less credible. The 'younger' respondents were interested in the private life of their favourite influencers related to travel, but their primary interest was in fashion, beauty and computer games.

Two answers were most frequently chosen on the question about reasons for using the internet. The first was the search for tourist information (chosen by $85 \%$ ) and the second was planning the travel route (by car, by bike, or on foot) which was given by $64 \%$ (Fig. 1). Nearly $90 \%$ of those under 35 and ca. $75 \%$ of older respondents looked for tourist information, and ca. $60 \%$ of 
them planned a route of travel. In the group of over 55 years of age, this amounted to ca. $33 \%$.

Numerous respondents also mentioned online payments (Fig. 1). Over 60\% made an online reservation or payment $(62 \%)$, for example for accommodation or a ticket, and over $50 \%$ of them looked for price discounts (52\%), for example on flight search sites. A smaller number of answers concerned online shopping (27\%), for example for tourist equipment. The more active users were those under 35 and ca. $70 \%$ of them made an online reservation or payment, ca. $60 \%$ looked for price discounts, and ca. 30\% chose online shopping. Of the 'older' respondents ca. 50\% made an online reservation or payment, ca. $30 \%$ looked for discounts, and ca. $20 \%$ shopped online. In turn, those living in cities with a population of over 500,000 preferred to look for price discounts on the internet $(63 \%)$, whereas respondents from smaller cities more frequently shopped online (34\%).

The majority of respondents had purchased tourist services on the internet at least once (76\%), and $33 \%$ of them had made group purchases. This group more frequently looked for tourist information before travelling $(88 \%)$. Over $80 \%$ of evaluated online payment as safe $(85 \%)$, however around a quarter considered online payments as an unsafe activity (23\%) after making an online purchase. Online shopping was most frequently done by respondents between 26 and 35 (89\%), and in the case of group purchases $(46 \%)$. Statistically significantly, women most frequently made group purchases $\left(71 \%\right.$; $\chi^{2}$ Pearson test, $p=0.018$ ). The age group between 26 and 35 had high confidence in the security of online payments (94\%). Respondents living in cities more frequently purchased on the internet (ca. 80\%) than those from rural areas (ca. 50\%), but additionally, those from smaller cities and towns made group purchases twice as often ( $43 \%)$.

\subsection{EVALUATION OF DIGITAL TOOLS}

The respondents were asked to choose between analogue and digital tools to indicate which was more useful at the stage of searching for tourist information and services, and purchasing. Most frequently they chose digital tools (Table 2), but there were two exceptions: the opinions of family or friends $(71 \%)$ and printed brochures $(55 \%)$.

Over $50 \%$ of respondents between 15 and 35 would rather use digital tools (aside from the opinion of family or friends). While those over 35 used analogue tools more frequently, similar to those who had completed vocational education. Respondents living in rural areas preferred purchasing at a travel agency (over $50 \%$ of respondents). However, those from cities with a population of over 500,000 preferred printed sources of information: maps $(52 \%)$ and brochures $(64 \%)$ and those from smaller cities chose online maps (68\%) and mobile applications (53\%).
In the opinion of the majority of respondents who took part in the focus groups, users of ICT were tourists under 40 years of age. However, the growing popularity and availability of selected digital tools, such as smartphones, and changes in the commercial offer provided by mobile networks influence consumer buying behaviour, including consumers from older generations. This in a sense forces an individual to learn how to use digital tools and sources.

On a five-point scale, the respondents evaluated the digital tools that facilitate mobility as the most useful with examples such as GPS navigation (4.43), online maps (4.25) and online public transport timetables (4.21). Online reservation and payment tools were also evaluated as relatively useful (4.12). The respondents preferred websites of visited destinations (4.12) and of accommodation facilities (4.01), rather than mobile applications (3.72) and social media such as blogs and vlogs (3.71), rating systems and online forums (3.51), and Facebook (3.29)

In the individual age groups, respondents' answers were close to average, with the exception of those over 55 (lowest rates). Moderate correlations were observable in two cases. Those who used the internet to search for tourist information before travelling, evaluated the websites mentioned above as more useful (Spearman rank correlation $=0.31$ and 0.33 ). Whereas those who were users of social media in the context of travel, evaluated social media as more useful (Spearman rank correlation $=0.31$ ).

For the 'younger' respondents, the use of digital tools was not always related to facilitating travel planning and arrangements. They rather treated digital tools as 'accompanying' a journey, for example when sharing photographs of a school trip on social media or playing games on smartphones when they were travelling in a coach to a destination. The influence of trends and peer groups on needs related to using digital tools was also emphasized in this age group, for example using particular smartphone models or particular mobile applications. The 'older' respondents also noticed this kind of motivation for the use of digital tools, however for them facilitating travel planning and arrangements had major significance. Above all, they emphasized the usefulness of information resources on the internet, in contrast to 'younger' respondents who emphasized the entertainment aspect. This does not mean that online entertainment had no significance at all for 'older' participants (Fig. 2). Examples of the most important aspects of digital tools given by the 'older' respondents were access to information on the internet, GPS navigation and online maps, and online reservation or payments. Their knowledge range and level, as well as skills in using the functions of digital tools, were higher than the younger age group, as their age allowed them to make purchases in online stores and use online payments more frequently. 
Table 2. Choice between tools allowing access to tourist information and services (\%)

\begin{tabular}{|c|c|c|c|}
\hline \multicolumn{4}{|c|}{ Tools allowing access to tourist information and services } \\
\hline analogue tools & $\begin{array}{c}\text { percentage } \\
\text { of answers (\%) }\end{array}$ & digital tools & $\begin{array}{c}\text { percentage } \\
\text { of answers (\%) }\end{array}$ \\
\hline Guidebook & 41 & Website & 59 \\
\hline Printed map & 41 & Online map & 59 \\
\hline Leaflet & 55 & Mobile application & 45 \\
\hline Tourist information bureau & 31 & Website & 69 \\
\hline Purchasing service at travel agency & 45 & Purchasing service on the internet & 55 \\
\hline Opinion of family or friend & 71 & Online review & 29 \\
\hline Photo album & 40 & Virtual tours & 60 \\
\hline
\end{tabular}

Source: author.

\section{SUMMARY}

The development of ICT has extended access to tourist information and services through digital channels of distribution such as the internet and portable devices, mainly smartphones. Tourists used ICT before travelling. The greatest interest and the highest rates of digital tool usefulness were observable in those that provided access to tourist information in the widest sense, and facilitating travel arrangements mainly with regard to planning, transport and tourist attractions. On the basis of these results, using the example of respondents from the Małopolska Voivodeship, it can be stated that ICT has a major influence on tourist experience. This area may be interesting for further research.

On the basis of respondents' answers, we can establish the group of tourists who are more active in the use of ICT. They are aged between 20 and 40 (which corresponds to generation $\mathrm{Y}$ ) use digital tools not only as an information source and access tool related to tourist information and services, but also to social media activity in the context of travel.

However, despite a relatively high public interest in using ICT on the tourism market in Poland numerous tourists still prefer to use traditional tools. That is why marketing communication and information policy should be realised 'bi-directionally' by actors in the tourist economy.

\section{ENDNOTE}

${ }^{1}$ Results presented in the paper are a part of research financed from 2012 to 2015 by Project 'Małopolska scholarship fund for Ph.D. Students' of Małopolska Enterprise Centre, Marshall Office of Małopolska Voivodeship in Kraków and also financed from 2013 to 2016 by DSC funds of Faculty of Biology and Earth Sciences, Jagiellonian University in Kraków from projects K/DSC/001787 and K/DSC/002377. Research results are a part of dissertation entitled 'Use of information and communication technology in promotion and tourist information on the example of municipalities of Małopolska Voivodeship'.

\section{BIBLIOGRAPHY}

Amaro, S., Duarte, P. (2015). An integrative model of consumers' intentions to purchase travel online. Tourism Management, 46, 64-79.

Berbeka, J. (2017). Analiza wykorzystania technologii informacyjnych i komunikacyjnych przez odwiedzających Kraków. In J. Berbeka, K. Borodako (eds), Technologie informacyjne i komunikacyjne na rynku turystycznym (pp. 153-171). Warszawa: Wydawnictwo C.H. Beck.

Buhalis, D. (2003). eTourism: Information technology for strategic tourism management. Essex: Pearson Education Limited.

Buhalis, D., Law, R. (2008). Progress in information technology and tourism management: 20 years on and 10 years after the Internet - The state of eTourism research. Tourism Management, 29 (4), 609-623.

Buhalis, D., O'Connor, P. (2005). Information communication technology revolutionizing tourism. Tourism Recreation Research, 30 (3), 7-16.

Buhalis, D., Leung, D., Law, R. (2011). eTourism: Critical information and communication technologies for tourism destinations. In: Y. Wang, A. Pizam (eds), Destination marketing and management: Theories and applications (pp. 205-224). Oxford: CAB International.

Gaworecki, W.W. (2007). Turystyka. Warszawa: Polskie Wydawnictwo Ekonomiczne.

Giddens, A. (2008). Socjologia. Warszawa: Wydawnictwo Naukowe PWN.

Gretzel, U., Sigala, M., Xiang, Z., Koo, Ch. (2015). Smart tourism: Foundations and developments. Electronic Markets, 25 (3), 179-188.

Hall, M.C. (2006). Space-time accessibility and the TALC: The role of geographies of spatial interaction and mobility in contributing to an improved understanding of tourism. In: R. Butler (ed.), The tourism area life cycle: Conceptual and theoretical issues. Part 2 (pp. 83-100). Clevedon-Buffalo-Toronto: Channel View Publications.

Horner, S., Swarbrooke, J. (2016). Consumer behaviour in tourism. Oxon-New York: Routledge.

Jakubowska, M. (2018). Diagnoza form turystyki popularyzowanych przez blogerów podróżniczych w Polsce. Studia Oeconomica Posnaniensia, 6 (10), 76-92.

Jaremen, D.E., Michalska-Dudek, I., Rapacz, A. (2016). Wirtualizacja zachowań konsumentów na rynku turystycznym jako źródło wiedzy w podejmowaniu decyzji marketingowych. Studia i Prace Wydziatu Nauk Ekonomicznych i Zarzadzania Uniwersytetu Szczecińskiego, 43 (2), 85-93. 
Jednoralska, A. (2016). Profil polskiego blogera podróżniczego - blogerzy podróżniczy jako inicjatorzy alternatywnego podróżowania wśród Polaków. Turystyka i Rekreacja, 13 (2), 29-33.

Kachniewska, M. (2011). Wpływ nowych technologii na rynek usług pośredników turystycznych. Zeszyty Naukowe Kolegium Gospodarki Światowej, 32, 239-258.

Kachniewska, M. (2014). Big data analysis jako źródło przewagi konkurencyjnej przedsiębiorstw i regionów turystycznych. Folia Turistica, 32, 35-54.

Kachniewska, M. (2017). Zmiany na rynku turystycznym. Nowe modele biznesowe i polityka turystyczna. Studia Oeconomica Posnaniensia, 5 (4), 183-207.

Kim, D.-Y., Park, J., Morrison, A.M. (2008). A model of traveller acceptance of mobile technology. International Journal of Tourism Research, 10, 393-407.

Kotler, P., Bowen, J.T., Makens, J.C. (2006). Marketing for hospitality and tourism. Upper Saddle River: Prentice-Hall.

Kowalczyk, A. (2000). Geografia turyzmu. Warszawa: Wydawnictwo Naukowe PWN.

Kubiak, K. (2015). Ocena wybranych aplikacji mobilnych w opinii użytkowników. Zeszyty Naukowe Uniwersytetu Szczecińskiego, 875. Problemy Zarządzania, Finansów i Marketingu, 41 (2), 83-93.

Law, R., Buhalis, D., Cobanoglu, C. (2014). Progress on information and communication technologies in hospitality and tourism. International Journal of Contemporary Hospitality Management, 26 (5), 727-750.

Lisowska, A., Wieszaczewska. A. (2017). Santiago de Compostela jako ważna destynacja turystyki pielgrzymkowej - obraz pielgrzymowania w narracjach blogów podróżniczych. Turystyka Kulturowa, 3, 74-95.

Majewska, J., Napierała, T., Adamiak, A. (2016). Wykorzystanie nowych technologii i informacji do opisu przestrzeni turystycznej. Folia Turistica, 41, 309-338.

Marciszewska, B. (2010). Produkt turystyczny a ekonomia doświadczén. Warszawa: Wydawnictwo C.H. Beck.

Meyer, B. (2015). Współczesne trendy w turystyce i rekreacji. In: B. Meyer (ed.), Obstuga uczestników turystyki i rekreacji (pp. 29-33). Warszawa: Wydawnictwo Difin.

Mika, M. (2014). Założenia i determinanty podtrzymywalności lokalnego rozwoju turystyki. Kraków: Instytut Geografii i Gospodark Przestrzennej Uniwersytetu Jagiellońskiego w Krakowie.

Morozova, I. (2016). Blog podróżniczy jako przestrzeń dla kreowania i komunikowania wzorców podróży. Folia Turistica, 40, 119-133.

Munar, A.M., Jacobsen, J.K.S. (2014). Motivations for sharing tourism experiences through social media. Tourism Management, 43, 46-54.

Neuhofer, B., Buhalis, D., Ladkin, A. (2012). Conceptualising technology enhanced destination experiences. Journal of Destination Marketing \& Management, 1 (1-2), 36-46.

Neuhofer, B., Buhalis, D., Ladkin, A. (2014). A typology of technology-enhanced tourism experiences. International Journal of Tourism Research, 16 (4), 340-350.

Niemczyk, A. (2017a). Rola technologii mobilnych na rynku turystycznym. In: J. Berbeka, K. Borodako (eds), Technologie informacyjne $i$ komunikacyjne na rynku turystycznym (pp. 93-116). Warszawa: Wydawnictwo C.H. Beck.

Niemczyk, A. (2017b). Aplikacje mobilne jako determinanta zachowań turystycznych (na przykładzie Krakowa). Prace Naukowe Uniwersytetu Ekonomicznego we Wrocławiu, 473, 370-381.

Niininen, O., Buhalis, D., March, R. (2007). Customer empowerment in tourism through consumer centric marketing (CCM). Qualitative Market Research: An International Journal, 10 (3), 265-281.

Panasiuk, A. (2015). Nowe technologie informacyjne w kształtowaniu innowacji na rynku turystycznym. Rozprawy Naukowe Akademii Wychowania Fizycznego we Wrocławiu, 49, 99-106.
Pawłowska, A. (2015). Turysta 2.0 - wyniki badania ankietowego nt. wykorzystania nowych technologii przez turystów w województwie małopolskim. Episteme. Czasopismo Naukowo-Kulturalne, 2 (23), 271-282.

Pawłowska, A. (2016a). Tourists and social media: Already inseparable marriage or still a long-distance relationship? Analysis of focus group study results conducted among tourists using social media. World Scientific News. International Scientific Journal, 57, 106-115.

Pawłowska, A. (2016b). Aplikacje mobilne jako nowe narzędzie w informacji turystycznej. Wyniki badań przeprowadzonych w województwie małopolskim. In: I. Miciuła, I. Nowakowska-Grunt (eds), Wybrane aspekty w zarzadzaniu organizacja w XXI w. Innowacje - Gospodarka - Spoteczeństwo (pp. 371-383). Katowice: Wydawnictwo Naukowe Sophia.

di Pietro L., di Virgilio F., Pantano E., 2012, Social network for the choice of tourist destination: Attitude and behavioural intention. Journal of Hospitality and Tourism Technology, 3 (1), 60-76.

Poczta, J., Mariianchuk, M. (2013). Samoświadomość turysty kulturowego a wizualność turystycznego świata, powszechność fotografii i ich wpływ na jakość turystycznego przeżywania. Turystyka Kulturowa, 11, 32-47.

Rasińska, R., Siwiński, W. (2015). Aplikacje mobilne jako innowacyjne źródła informacji turystycznej dla studentów. Rozprawy Naukowe Akademii Wychowania Fizycznego we Wroctawiu, 50, 74-80.

Richards, G. (2002). Tourism attraction system. Exploring cultural behavior. Annals of Tourism Research, 4 (29), 1048-1064.

Rudnicki, M. (2017). Rozwiązania informacyjno-komunikacyjne w przedsiębiorstwach turystycznych. In: J. Berbeka, K. Borodako (eds), Technologie informacyjne i komunikacyjne na rynku turystycznym (pp. 31-64). Warszawa: Wydawnictwo C.H. Beck.

Seweryn, R. (2015). Profil turysty pozyskującego informacje o destynacji z mediów społecznościowych (na przykładzie odwiedzających Kraków). Prace Naukowe Uniwersytetu Ekonomicznego we Wroctawiu, 379, 439-447.

Smul, P. (2013). Wykorzystanie Internetu w sprzedaży i promocji usług turystycznych. Zeszyty Naukowe Wyższej Szkoły Humanitas. Zarządzanie, 14 (1), 88-104.

Xiang, Z., Gretzel, U. (2010). Role of social media in online travel information search. Tourism Management, 31, 179-188.

Xiang, Z., Magnini, V.P., Fesenmaier, D.R. (2015). Information technology and consumer behavior in travel and tourism: Insights from travel planning using the internet. Journal of Retailing and Consumer Services, 22, 244-249.

Zajadacz, A. (2014). Pokolenia X, Y, Z a fenomen turystyki. In: J. Śledzińska, B. Włodarczyk (eds), Międzypokoleniowe aspekty turystyki (pp. 55-68). Warszawa: Wydawnictwo PTTK Kraj.

Zajadacz, A. (2017). Dyssatysfakcja w przestrzeni turystycznej. Negatywne opinie użytkowników Tripadvisor na temat głównych atrakcji turystycznych wybranych miast w Polsce. Prace i Studia Geograficzne, 62 (3), 63-88.

Zawadzki, P. (2018). Aplikacje mobilne jako element systemu informacji turystycznej. Zeszyty Naukowe Uniwersytetu Ekonomicznego w Krakowie, 4, 85-101.

Zehrer, A., Pechlaner, H., Holzl, B. (2005). The development of a Destination Management System (DMS) in South Tyrol. Anatolia, 16 (2), 147-161.

Zeng, B., Gerritsen, R. (2014). What do we know about social media in tourism? A review. Tourism Management Perspectives, 10 27-36.

Article received: 9 September 2019 Accepted: 4 November 2019 